\title{
Non Pharmacological Therapy in Case Study Obstacles to Physical Mobility Post Sectio Caesaria
}

\author{
Sri Wahyuningsih ${ }^{1 *}$, Nurul Hayati ${ }^{2}$, Hesti Adi Safitri ${ }^{3}$ \\ 1,2,3Vocational Nursing Program, Faculty of Nursing, Universitas Jember, Indonesia; \\ sriwahyuningsih@unej.ac.id (Corresponding Author)
}

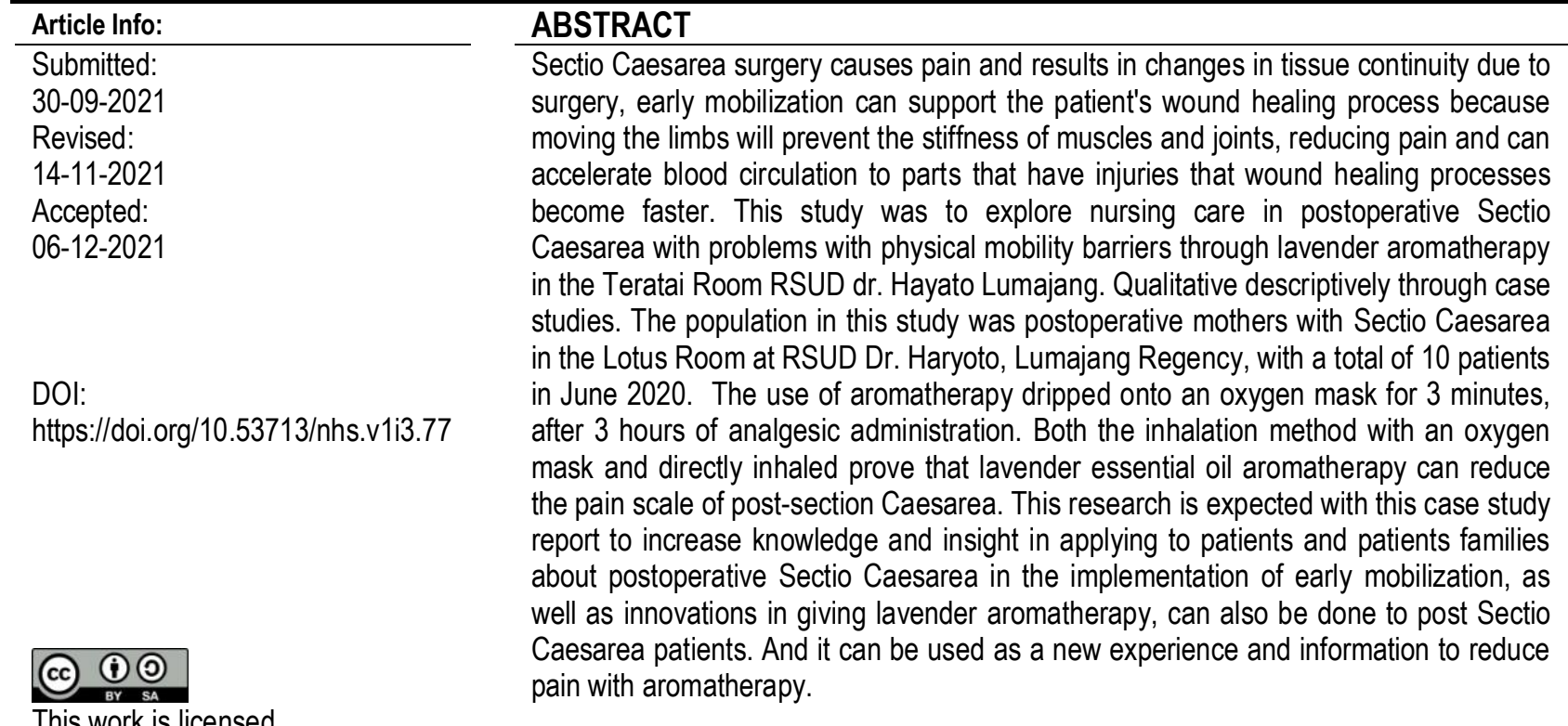

This work is licensed under CC BY-SA License.
Keywords: lavender aromatherapy; physical mobility; sectio caesarea

\section{INTRODUCTION}

Birth with Sectio Cesarea is the last alternative in labor. This is due to high-risk factors, both risks for mother and baby (Wijaya, 2019). There are several medical actions that can cause pain, namely the surgical procedure in postSectio Caesarea patients, which includes impairment, functional limitation, disability Impairment includes acute pain at the site of surgery, fear, and limitation of the Scope of Motion, functional limitation includes the inability to stand, walk, and ambulate and Disability includes activities that are disrupted due to limited range of motion due to pain and medical procedures (Nugroho T, 2010). The nurse's role, in this case, is to help clients gain self-control to minimize pain. Nonpharmacological pain management becomes cheaper, simple, effective, without adverse effects, and mothers can control their own pain complaints (Perry, and Potter, 2005) in a research journal conducted by (Safaah Siti, 2019). One of the non-pharmacological management that is often given is Aromatherapy so that it can be said to have the ability to provide a therapeutic effect in maternity nursing care. The effect of aromatherapy on comfort can be measured by looking at various indicators that show comfort, these indicators are the interpretation of aromatherapy itself will show the emotional response of fight or flight, the interpretation of the sense of comfort obtained from the effects of aromatherapy, the statement that aromatherapy improves performance, increases concentration, mind calmer, the soul becomes cooler (Price, and Wilson, 2005) in a research journal conducted by (Safaah Siti, 2019).

Lavender aromatherapy is able to affect the limbic system in the brain which is the center of emotion, memory, and mood or mood to produce endorphins and enkephalin neurohormones that have pain-relieving properties (Perez, 2003) in a research journal conducted by (Safaah Siti, 2019). The method of giving aromatherapy carried out on samples is slightly different between researchers Hadi and Hamid (2011) in a research journal conducted by (Herlyssa, 2018) saying that researchers used 10\% lavender essential oil aromatherapy, dripped 3 drops on a tissue, and then given to the post-Sectio Caesarea mother 24 hours and inhaled for 5 minutes at a distance of $10 \mathrm{~cm}$, then measured the pain scale (post-test) in the treatment group and the control group, after 5 minutes aromatherapy was given by showing 
a pain scale image from 1-10 according to the observation sheet. The use of aromatherapy dripped onto an oxygen mask for 3 minutes, after 3 hours of analgesic administration. Both the inhalation method with an oxygen mask and directly inhaled prove that lavender essential oil aromatherapy can reduce the pain scale of post-Sectio Caesarea.

According to a research journal conducted by (Zetira, 2017) the name lavender comes from the Latin "lavera" which means refreshing. Lavender flowers (Lavandula angustifolia) are small, bluish-purple in color, and plant heights up to $72 \mathrm{~cm}$ from the southern Mediterranean region to tropical Africa and east to India. Lavender includes perennials, grasses, short shrubs, and small shrubs. This plant also spreads in the Canary Islands, North and East Africa, southern Europe and the Mediterranean, Arabia, and India. Lavender flowers (Lavandula angustifolia) grow well in highland areas, with altitudes ranging from $600-1,350 \mathrm{~m}$ above sea level. Propagation by using seeds from lavender plants that are old and sown. When it grows, it can be transferred to a polybag. When the plant height has reached $15-20 \mathrm{~cm}$, it can be moved into a pot or can be planted in the yard.

Lavender aromatherapy is able to affect the limbic system in the brain which is the center of emotion, memory, and mood or mood to produce neuro-hormone endorphins and enkephalins which have pain-relieving properties, and serotonin which has the effect of relieving tension or stress and anxiety (Perez, 2003). ) in a research journal conducted by (Safaah Siti, 2019). Aromatherapy that is used by inhalation or inhaling will enter the limbic system where later the aroma will be processed so that we can smell the smell. When we inhale an aroma, its chemical components will enter the olfactory bulb, then into the limbic system in the brain. This will stimulate memory and emotional response. The hypothalamus acts as a relay and regulator, generating messages that must be received and then converted into action in the form of releasing electrochemical compounds in the form of endorphins and serotonin, so that they have a direct effect on the organ of smell and are perceived by the brain to give reactions that make physiological changes to the body, mind, soul, and produces a calming effect on the body so that it can reduce pain (Dewi, et al. 2013) in a research journal conducted by (Anwar Mutia, 2018).

The way essential oils work as aromatherapy is that essential oil molecule are received by receptor cells in the lining of the nose when inhaled and send signals to the brain. The role of electrochemical received by the olfactory center in the brain then stimulates the release of very strong neurochemicals into the blood which are then transported throughout the body. Molecules that are inhaled into the lungs can enter the bloodstream and are circulated throughout the body in the same way (Gidds \& Grosset, 2000) in a research journal conducted by (Herlyssa, 2018). Essential oils penetrate the skin pores and hair follicles when rubbed or massaged into the skin. Essential oils will enter the capillaries and then spread throughout the body. (Gidds \& Grosset, 2000) in a research journal conducted by (Herlyssa, 2018). This condition results in a reduction in the pain scale in post-Sectio Caesarea mothers.

\section{METHOD}

The research design is qualitative with descriptive, the method used is a case study. This case study research explores a nursing problem with detailed boundaries, has in-depth data collection, and includes various sources of information. written in a narrative to describe the medical and nursing experience of one or several patients in detail for the purpose of improving treatment outcomes, developing knowledge, and improving education in the field of nursing. This case study research was to explore the problem of nursing care in post-Sectio Caesarea patients as many as 10 respondents in the Lotus Room RSUD dr. Haryoto Lumajang in June 2020. Researchers will only take samples that are included in the inclusion and exclusion criteria that have been set by the researcher. The data collection instrument in this study was carried out using a pain level measuring instrument which was used by observation. The measuring instrument used by researchers in measuring pain intensity refers to the level of pain with a Numerical Rating Scale measuring instrument with a pain scale of 0-10 to determine the final level of pain. Pain assessment was carried out before and after being given lavender aromatherapy in the treatment group.

\section{RESULT}

The results of the assessment in patients had main complaints, namely disturbances when doing right and left tilting activities, sitting, standing, walking, and doing early mobilization. Interventions were carried out by doing early mobilization in stages, measuring vital signs, collaboration with other medical teams, measuring pain scales, and independent nursing actions carried out by means of the first 6 hours of giving lavender aromatherapy. Nursing implementation has been carried out in accordance with existing interventions. The problem of physical mobility barriers can be resolved on the 3 rd day.

It is hoped that this case study report can increase knowledge and insight in applying to patients and patient families about post-Sectio Caesarea in the implementation of early mobilization, and innovations in giving lavender 
aromatherapy can also be done to post Sectio Caesarea patients. And it can be used as a new experience and information to reduce pain with aromatherapy.

Aromatherapy lavender essential oil 10\% dripped 3 drops in hot water then given to the post-Sectio Caesarea mother for 24 hours and inhaled for 5 minutes at a distance of $10 \mathrm{~cm}$, then measured the pain scale (post-test) in the treatment group and the control group, after 5 minutes Aromatherapy is given by showing an image on a pain scale from 1-10 according to the observation sheet. Aromatherapy dripped onto an oxygen mask for 3 minutes, after 15 minutes after analgesic administration. Both the inhalation method with an oxygen mask and directly inhaled prove that lavender essential oil aromatherapy can reduce the pain scale of post-Sectio Caesarea.

\section{DISCUSSION}

In postoperative Sectio Caesarea patients with nursing problems physical mobility barriers which indicate the goal can be achieved according to the planned time target ranging from 3-4 days of treatment by showing the following outcome criteria, the patient can show mobility as evidenced by the following indicators: balance, coordination, body performance, joint, and muscle movement, walking, moving easily, the patient can show a shift from a lying to a sitting position, the patient can show a shift from a sitting to a standing position, the patient can show when walking. And for the innovation of giving lavender aromatherapy, it must pay attention to the patient's condition, before giving the therapy the researcher must review the history of allergies to odors. It can be used as a reference source in carrying out early mobilization and giving lavender aromatherapy, and the problems that researchers experience, one of which is allergies experienced by postoperative Sectio Caesarea patients can be overcome from a complete assessment so that maximum therapy is given and is expected to modify the implementation of nursing interventions that are appropriate. has been done, it would be nice if further researchers could develop innovations in giving lavender aromatherapy to post-Sectio Caesarea patients.

\section{CONCLUSION}

Giving lavender aromatherapy can increase knowledge and insight in applying to patients and their families about postoperative Sectio Caesarea in reducing pain in the implementation of early mobilization.

\section{ACKNOWLEDGEMENT}

Thank you to all respondents for post-Sectio Caesarea in June 2020 and health workers in the Lotus Room of RSUD dr. Haryoto Lumajang. Thank you to the University of Jember for facilitating researchers and all nursing and medical parties at RSUD dr. Haryoto Lumajang has given full support to the implementation of this case study.

\section{REFERENCES}

Anwar, M., T. Astuti, and M. Nobility. (2018a). The effect of lavender aromatherapy on reducing pain intensity in postoperative Sectio Caesarea patients. Scientific Journal of Nursing Sai Betik. 14(1):84-90.

Anwar, M., TA, and MB. (2018b). The effect of lavender aromatherapy on reducing pain intensity in postoperative Sectio Caesarea patients. Journal of Nursing. 1(XIV):84-90.

Herlyssa, J. and EDW. (2018). Lavender essential oil aromatherapy has a dominant effect on the 24-hour pain scale post-Sectio Caesarea. Journal of Health. 2(9):192-198.

Kamsatun, WF. (2018). Early mobilization of post Sectio Caesarea mothers at the Soreang Hospital. journal of health science and technology. Journal of Health Science and Technology. 2(5):149-163.

Lema, LK. (2019). Relationship The level of knowledge of early mobilization with early mobilization behavior of postpartum sectio caesarea (sc) mothers in the Sasando and flamboyant rooms at the hospital prof. dr. w. z johannes kupang. CHMK Midwifery Scientific Journal. 2(1):1-1.

Lusia Karolinda Lema, RM \&. M. (2019). The relationship between the level of knowledge of early mobilization and early mobilization behavior of post partum sectio caesarea (sc) mothers in the sasando and flamboyant rooms of the hospital prof. dr. w. z johannes kupang. Chmk Midwifery Scientific Journal. 1(2)

Mutia, N. \&., (2018). The Relationship of Post Sectio Caesarea Early Mobilization with Surgical Wound Healing in the Obstetrics Room of Dr. Fauziah Hospital, Juang City District, Kab. Biruen. Healthcare Technology and Medicine, 4(2), pp. 187-93.

Nadiya, S. and C. Mutiara. (2018). The relationship between early post sectio caesarea (sc) mobilization with surgical wound healing in the obstetrics ward of dr. Fauziah, Kota Fighting District, Bireuen Regency. Journal Of Healthcare Technology And Medicine. 4(2):187-195.

Safaah, S. (2019). Differences in the effectiveness of lavender aromatherapy and peppermint aromatherapy on pain. Journal of 
Bionursing. 1(1)

Siagian, NA, SN, and ABM. (2019). The relationship between early mobilization and wound healing after sectio caesarea. Journal of Nursing Research. 1(2)

Sumaryati. (2018). The relationship between early mobilization and the level of independence of post sectio caesarea patients in the Mawar Ward of the Temanggung Hospital. Indonesian Journal of Nursing Research. 1(1):20-28.

Taviyandi. (2019). Psychological adaptation to primigravida postpartum mothers (taking hold phase) sectio caesarea and normal delivery. Journal of Nursing Research. 1(5):76-82.

Triana, A. and Livana. (2018). Relationship between family support and anxiety for early mobilization of postoperative patients. Journal of Nurses and Midwifery. 3(5)

Wahyuningsih. (2019). Textbook of Maternity Nursing. Issue 1. Bondowoso: KHD Production.

Wahyuningsih, S. (2019). The Post Partum Nursing Teaching Textbook is Completed with a Nursing Student Practicum Preparation Guide. Yogayakarta: CV Budi Utama.

Yulianti. (2018). Factors AffectingHealing Process

Yunarsih's. (2019). Early mobilization of post-op sectio caesarea. nursing journal. Journal of Nursing. 2(11):111-118.

Zetira. (2017). Aromatherapy of Lavender Flowers (Lavandula Angustifolia) In Lowering. Majority 